\title{
DESIGNING ONLINE MARKETPLACE TO RESOLVE MARKETING PROBLEM FOR SMALL AND MEDIUM ENTERPRISES (SMEs)
}

\author{
Aditya Hermawan *) \\ Aniek Murniati **)
}

\begin{abstract}
The study aims to design an online marketplace to provide solutions that faced by Small and Medium Enterprises (SMEs). One of the problems that faced by SMEs is the difficulty to market their products online. One of the solutions that we provide is by designing an online marketplace to solve their marketing problems effectively. We found that SMEs have attempted to market their products through social media such as facebook, twitter and others. In addition, some SMEs also have a website and advertise their products through online advertising. However, many of those who did not know how to market products online in order to increase sales. We designed an online marketplace for SMEs based on the concept of e-commerce to resolve the problems faced by SMEs, the effective marketing. The online market design is made taking into account the needs of SMEs as well as customer needs. Therefore, this study was conducted to SMEs in Malang, East Java, Indonesia and the people who often make purchases online.With the existence of the online market, SMEs can increase sales lead to increased profits for SMEs.
\end{abstract}

Keywords: Online Market, E-Commerce, Marketing

\section{INTRODUCTION}

\subsection{Research Background}

Small and Medium Enterprises (SMEs) face a variety of problems in running the business. One of the problems faced by SMEs is difficult to market their products. Most SMEs have the skills to create a product or service and rely solely on conventional marketing and simply reach customers in the area around SMEs only, then the impact on the sales turnover was not boosted and accompanied with increasing production costs. The demands of customers who want easy access to information about the products they want from the seller.

Limitations customers to access product information from vendors create resistance to the seller (Ram and Jagdish, 1989). Studies Research Center of Integrated Enterprise Services Cooperative, Micro, Small and Medium Enterprises (MSME Plut) Surakarta period January - March 2016, showed that 38\% of SMEs in the city of Solo constrained Marketing (http://www.etalasebisnis.com/berita/ukm/2045/pemasaran-masih-menjadi-masalah-terbesar-bagi-umkmsurakarta.html). For small-scale businesses such as SMEs would have a different marketing strategies to large corporations. SMEs usually have a limited marketing budget, so that the necessary creativity to find an effective way to market a product with low marketing costs (http://www.beonesolution.com/blog/strategi-bisnis-ukm-pemasaran-yang-efektif-to-SMEs-small-medium-business/). With a limited budget for marketing their products widely, it can have an impact on customer difficulties in obtaining information about the products marketed SMEs.

Isaac (2005) explains that the lack of access to information, especially the information about the market, making obstacles for SMEs in marketing their products. With limited access to such information, resulting in low impact on the market orientation and competitiveness at the global level. Until ultimately resulted SMEs can not steer clear of their business development and lead to not focus the development of SMEs. Thus, the weakness of SMEs in marketing their products is access to information on products marketed broadly hard earned customers where marketing of SME products on average are still marketed only the area around, but the quality of the product has been able to reach out to other countries to export. With only marketed in the surrounding area, SMEs tend to only control the market is relatively narrow so 
that customers who are outside the area around the SMEs difficulties or even no information on the SME products. To overcome these problems, information technology is needed in order to market its products widely so that customers can obtain information on the marketed product.

Developments in information technology today provides an opportunity for SMEs to provide their product information to the public. Along with the development of information technology, not least SMEs who do marketing its products by using information technology. Various attempts were made to market their products by utilizing information technology, such as through social media or have their own websites that are specific to their own products and are usually in the form of an online store. There is also market their products through online selling sites. In other words, SMEs have tried as much as possible to market their products by utilizing information technology.

The use of information technology by SMEs to market their products online provide ideas for designing an online market. Some sites are used as a reference in designing the online market include the www.tokopedia.com, www.olx.com, and www.indonetwork.com. The fifth site was selected as a reference in designing the online market because it is the site that implements the concept of customer to customer, which provides an opportunity for sellers to market their products online to customers. Therefore, the online market will be designed to apply the concept of customer to customer making it easier for SMEs to market their products online making it easier for customers to access information about the products they want.

\subsection{Research Problem}

Based on the above points of thought, the authors are interested to know which is the best online marketplace system that can help to overtake Small and Medium Enterprises (SMEs) their market problem?

\subsection{Research Purpose}

This research aims to design the best online marketplace system to provide solutions that faced by Small and Medium Enterprises (SMEs).

\section{THEORETICAL FRAMEWORK}

\subsection{Theoretical Framework}

\subsubsection{Small and Medium Enterprises (SMEs)}

Based on Presidential Decree no. 99 In 1998, the definition of Small Business is: "Economic activity people are small-scale business sector in the majority of the business activities of small and need to be protected to prevent it from competition is not healthy." According Hallberg (2008: 1), SMEs are a group heterogeneous which has a variety of sophistication and skill, and operates in a market and a social environment that is very different. Some SME is a business that is dynamic, innovative and growthoriented. But other traditional businesses that are quite satisfied with the existing conditions.

Law No. 9 of 1995 provides criteria for SMEs as follows:

1. The net worth of Rp. 200.000.000, - (two hundred million rupiah) not including land and buildings.

2. Have an annual sales turnover of Rp. 1.000.000.000, - (One Billion Rupiah).

3. Owned by Indonesian citizens.

4. Stand-alone, not subsidiaries or branches of companies that are not owned, controlled or affiliated directly or indirectly with Medium Business or Large Business.

5. Shaped individual business, a business entity that is not a legal entity, or entities with legal status, including cooperatives.

Based on such understanding, it is clear that SMEs are companies that have limitations in terms of venture capital, so the impact on marketing operations. Venture capital constraints forcing SMEs to market their products effectively, where customers can obtain accurate information regarding the products marketed by SMEs. Marketing of products made by the SMEs during limited only to the area around the SMEs are located, so that it is less extensive marketing coverage. Less wide scope of marketing these 
products make customers who are outside the area around SMEs difficulty or even not be able to obtain information about the products offered SMEs.

\subsubsection{Marketing}

Kotler (2000: 11) explains that marketing is a social and managerial process in which individuals and groups obtain their needs and desires by creating, offering and exchanging something of value to one another. This definition is based on the core concept of the needs, desires, and demands, product value, value and satisfaction, exchange, transactions and relationships, markets and marketing and marketers. Based on this definition, if a customer trouble or even not able to obtain the information they need about the products they want, then the marketing is done by the SMEs would be ineffective. Therefore, the online market will have to be designed to meet the needs of customers and SMEs as the seller. Customers need accurate information about the products offered, the information concerning the procedure of online transactions, information on SMEs as parties that offer products, information on transactions executed, and others. Similarly, SMEs also need information about the customer, information regarding the payments made by customers, and others.

\subsubsection{Online Marketplace}

Baum (Purbo, 2001) explains that e-commerce is a dynamic set of technologies, applications, and business processes that connect corporate, consumer, and certain communities through electronic transactions and trade in goods, services, and information that will be conducted electronically. According Fuady (2005), e-commerce is a business process by using electronic technology that links between businesses, consumers and the public in the form of electronic transactions and exchange / sale of goods, services, and information electronically. It can be concluded that the e-commerce $\neg$ the business processes that use information technology in the distribution of goods and electronics layanansecara from the seller to the buyer.

Thus, the online marketplace that would be designed to connect SMEs with the customer so that it can accommodate the needs of customers to SMEs. Therefore, an online marketplace that would be designed will apply the concept of Business to Customer (B2C). Business to customer (B2C). is a form of buy-sell products involving vending companies and end consumers are made electronically. Therefore, the online market provides facilities for SMEs to market their products to the general public or to other SMEs.

\section{RESEARCH METHOD}

The biggest problem that faced by many SMEs is to extent their market scope toward online landscape. Therefore, it takes an online marketplace that allows SMEs to market their products online and customers can access information about the products offered by SMEs. The online market can be designed using a qualitative approach, in which the targets of a qualitative research study was pla-pattern of behavior based on human behavior (Suparlan, 1994: 3-5), in this case the SMEs and customers. Poerwandari (1998: 17) explains that qualitative research is done for to explore the understanding toward phenomenon. Understanding in this case is the online marketplace designed based on the behavior of SMEs in finding an effective online market to increase sales as well as the behavior of customers who want to easily access information about the products they need from the seller. Qualitative research can declared as the construction of social reality, because the qualitative research views that knowledge not only experience on facts, but also the result of the construction of the ratio of the subject under study. The introduction of social reality on the subject and not on the object, this means the science results as well experiences constructed by the ratio. Therefore, the online market must be built based on the behavior of SMEs and customers, the online market that are designed to meet the needs of both parties.

Designed online market is the result of learning on the behavior of SMEs and customers. This is a phenomenon on the essentials of life in society, which overall are bound together and interact with each other. Therefore phenomenology is the proper perspective in designing an online marketplace that required by SMEs. This is because phenomenology is a principle study with the primary objective 
studying the essentials of life as well as the inter-relation matters thoroughly and carefully. Phenomenology as a perspective of this research will be based on the behavior of SMEs and customers to design the online market. SMEs and customer behavior can be described by the needs of SMEs to market online so that they can market its products widely and customer demand for accurate information about the products they want.

SMEs and customer behavior is a phenomenon which makes the method of User Centered Design (UCD) as an appropriate method in designing the online market. This is because UCD puts the user as the center of the system development process, and the purpose / nature, context and environment systems that are all based on the user experience (Kadir, 2008). In addition, UCD describes the functional requirements of the application that is designed, in this case the online market. Functional requirements of applications designed can be illustrated by making an explicit statement of user needs and the organization, the needs of SMEs to the online market so that they can market its products widely and customer demand for accurate information about the products they want. UCD itself is a new paradigm in the development of web-based system using participation and user experience in the design process. What is meant by the user is the person who will use or operate the system. In this case, the online market is SMEs and customers.

\section{RESEARCH RESULT AND ANALYSIS}

In designing an online marketplace that required by SMEs, the first step is to analyze the needs of the system. The purpose of the analysis is to understand the needs of the system in good faith requirements of the new system and develop a system to accommodate those needs. At this stage, the analytical study of the existing problems, including the type of system that has existed along with the problems that arise, needs of users of the new system, as well as functional requirements and application needs that accommodates the needs of users. Users are referred to in this case are SMEs and customers. Therefore, the new system will be designed to be able to accommodate the needs of SMEs and customers, so as to provide solutions to the problems faced by SMEs, namely marketing.

In the next stage of the analysis conducted on the feasibility of the system. Designed online market will have to have eligibility so that it can be used by users. Analysis of the feasibility of the system is done in four ways, namely:

1. Eligibility technology: Feasibility of technology related to the availability of technology system builder market. In terms of technology, the proposed online market deserve to be applied by SMEs so as to provide adequate information on the products offered to customers. This is because the use of information technology by SMEs and customers have done so far, so the design of the online market by leveraging existing information technology can be to be applied.

2. Legal Feasibility: Feasibility of law in terms of the intended use of the system, the legality of the materials for the system as well as in terms of the information generated. From the goal of making the system is fully carried out for commercial legal activities. In making the online market used software is open source, so that the legality of legally feasible to design the online market dibutuhkna by SMEs.

3. Operational Feasibility: designed online market can be said to be feasible operationally because there have been several similar systems and the use of information technology that has been carried out by SMEs and the Customer. Some e-commerce sites that use B2C concepts like www.indonetwork.com, www.tokopedia.com, and www.olx.com showed that the use of information technology by several businesses, including SMEs, have been carried out to the fullest in order to market their products.

4. Economic feasibility: In this economic feasibility, aspect to consider is the amount of funds that is strictly necessary to develop the system and the benefits derived by the system. The system is said to be economical if the benefits are obtained greater than the costs incurred. By utilizing the Internet, allows the manager to perform maintenance which resulted in cost efficient. The online market that are designed utilizing the Internet that facilitate the delivery of information and 
communication between SMEs and customers. Therefore, utilizing the Internet, then the cost will be more efficient as well as the time spent on running an online business is also relatively lebioh efficient.

The next stage is the analysis of the same system that has been running. Based on observations, some sites such as www.indonetwork.com, www.olx.co.id, www.tokopedia.com, had been run using B2C concept. B2C concept allows SMEs can offer its products widely to customers. Some of the above site provides information on the vendor to the customer so as to give an opportunity to the customers to communicate directly with the seller. Based on observations obtained the following results:

1. www.olx.co.id, www.tokopedia.com, and has implemented www.indonetwork.com User Interface (UI) that is excellent in providing ease of access to users. Can be seen on the site by using images and buttons are easy to understand.

2. To increase the productivity of users accessing the UI, www.olx.co.id, www.tokopedia.com, and www.indonetwork.com provides a search facility to allow users to search for and find the information they need. Users also do not need to bother to enter a keyword in this search facility. Because when users just by typing a few letters and have not completed fully keyword, the facility is capable of displaying the keyword in question automatically as shown above. It also provides related opsikeyword. So in search of information can be more quickly and efficiently.

3. To minimize the errors in data entry, the system makes the terms and conditions should be read first by first-time users to use online trading services on www.olx.co.id, www.tokopedia.com, and www.indonetwork .com. It is understood that www.olx.co.id, www.tokopedia.com, and www.indonetwork.com really concerned about the procedures used.

4. www.olx.co.id, www.tokopedia.com, and www.indonetwork.com provide feedback to the user in private, so that confidential information is asked by the user can only be seen by the www.olx.co.id, www.tokopedia.com, and www.indonetwork.com only. Due to maintain the confidentiality of the information right from both the user and the system.

5. The initial view web www.olx.co.id, www.tokopedia.com, and www.indonetwork.com which looks simple yet attractive with white background and symbols with a striking color as the core point of this web. Thus making the visitor's eyes directed straight to the point which is highlighted in this web. Then the second is about the layout of the icons and menu, which has a design web menu entirely shown so the user can know what the menu is brand wanted in the first gaze opened the first page, without having to open-open sub-menu. Another thing to note their presence hypertext pictorial and written on this website. Where it is easier for users to obtain information that is related to what users are looking for.

6. The term is often used in the buying and selling of products or services, the system www.olx.co.id, www.tokopedia.com, and www.indonetwork.com using language and images that is easily understood in just one glance. So users will immediately understand what the purpose of the text or images.

Based on the above observations, it can be made online market overview as follows:

1. The online market is an e-commerce site that implements the concept of $\mathrm{B} 2 \mathrm{C}$, which provides an opportunity for SMEs to expand the scope of its product marketing. This is because SMEs are given access to carry out sale and purchase transactions with customers, providing solutions for marketing problems faced by SMEs.

2. SMEs have access to perform transactions with customers. For that SMEs can display information and business profile and its product offerings, communicate with customers, validating payments made by customers, and so forth.

3. Customers have access to perform transactions with SMEs. Customers can make payments to SMEs confirmation on goods purchased, communicate with SMEs on product information offered, and others associated with the activity of buying and selling online.

4. The online market Administrators have access to manage sites online market and is responsible for the design, smooth operations, and can function as a mediator between SMEs and customers. 
Based on the overview of the online market, as mentioned above, can be made online market framework as follows:

Picture 1 Framework of Online Market

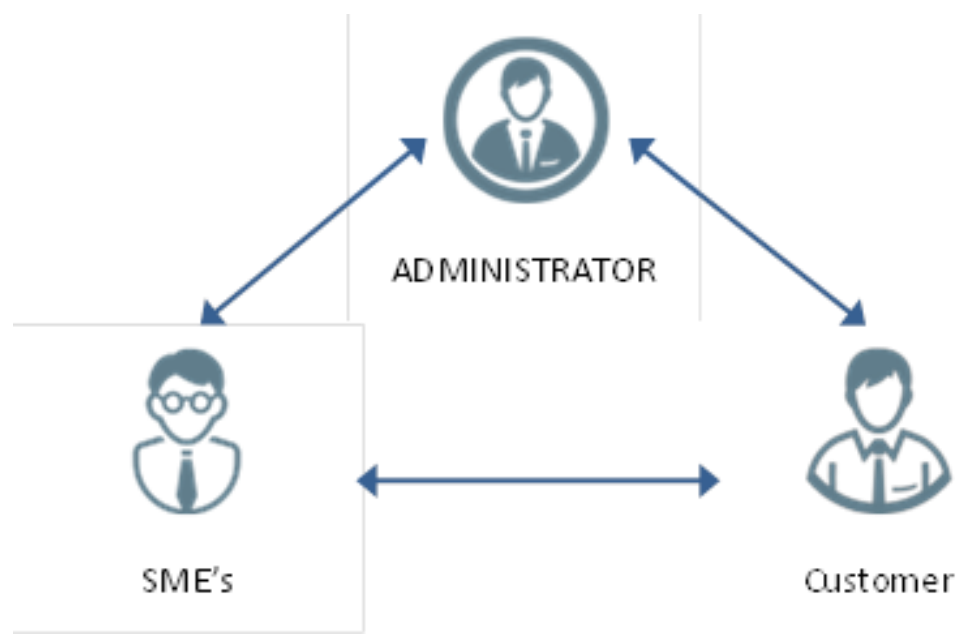

The framework of the online market, then the design can be made on the online market as follows:

1. Visitor's Page

Page visitors are the pages that were first opened by visitors. On the pages of this visitor, presented the following features, among others:

a. Home Page

On the homepage, the information presented on the 12 SMEs that have just signed up, 12 SME products, brief information on the Online Marketplace, and visitor statistics.

b. The list of SMEs

On this page, presented SMEs registered in the Online Marketplace as many as 20 SMEs per page. Visitors can click the button detail on each column of SMEs so that leads directly to the specific page of the SMEs. Customers can find out the profile of SMEs, the products are sold, a shopping cart, confirmation of payment, the contacts can be contacted, as well as other required.

c. List of SME's Products

On this page are presented information about products owned SMEs as many as 20 products per page. Visitors can click the button detail that leads directly to the specific page of SMEs in the product detail page. On that page, customers can find out information about a product in the form of product images, product specifications, prices, discounts, quantity of goods available, as well as other required. To be able to order products, so visitors must be registered as a customer in the Market Online.

\section{d. Related Searches Smes}

On this page, visitors can search by name and their SME SME temapt region is located. Visitors can charge by writing the name of the SMEs in the search form and choose the location of these SMEs, and then click the search button. This will bring up a list of SMEs that match the search criteria. Visitors can click the button detail that leads directly to the specific page of the SMEs. Customers can find out the profile of SMEs, the products are sold, confirmation of payment, the contacts can be contacted, as well as other required.

e. SME Product Search

On this page, visitors can search for products of SMEs by product name and pricing of these products. Visitors can write the name of SME products in the search form and choose the price of the product, and then click the search button. This will bring up a list of SME products that matches the search criteria. Visitors can click the button detail that leads directly to the specific page of SME products. Customers can find out information about a product in the form of product images, 
product specifications, prices, discounts, quantity of goods available, as well as other required. To be able to order products, so visitors must be registered as a customer in the Market Online.

f. Registration of SMEs

This page is only for SMEs that have not been registered in the Market Online to be able to join as a member at the Online Market. You do this by filling out a registration form that was provided and then clicking the button list. After that SMEs will directly log-in as a member of the Online Marketplace with access to as SMEs.

g. The customer registration

This page is only for visitors who want to become regulars in the Market Online. You do this by filling out a registration form that was provided and then clicking the button list. After that the visitors will be logged in as a member of the Online Marketplace with access as a customer.

h. Log-In for SMEs and Customers

This page is only intended for Log-in member of the Online Marketplace. Both SMEs and Customers can log-in by entering their username and password each and if appropriate it will log-in to the respective pages as SMEs and customers.

i. Market Online Profile

This page is intended to provide information about the Online Market. Visitors can find the profile of the Market Online. In addition, visitors can contact the Market Administrator Online form contact person messages and information that has been provided.

2. SME's Page

This page is only for SMEs. To gain access to these SMEs, the visitor can log-in on the log-in and must be registered as SMEs in the Market Online. In these SMEs, presented the following features, among others:

a. SME's Account

This page presents information on SMEs account. SMEs can change Username and Password periodically or not.

b. SME's Profile

This page provides information about the profile of SMEs. SMEs can provide complete information about the business being operated. The information that can be presented by SMEs is a business name, business location, business establishment, TIN, type of business, type of business, number of contacts that can be contacted, e-mail, website address if it has, as well as SMEs can include information about your bank account for transfer payment for ordering the products by the Customer.

c. Product's

This page presents information on SME products. SMEs can provide complete information about the products offered. The information presented is the product name, product price, the physical specifications of the product, as well as product photos. SMEs can add, change or delete products that omission.

d. Sales Order's

These pages provide information about ordering products made by customers. The information presented is the order code, the booking date, customer name, customer contact info, list of products ordered, the total amount to be paid by the customer, product delivery address.

e. Payment Confirmation

This page provides information about the confirmation of the payment made by the customer. Once the customer ordered goods, the customer must make a payment to the account of SMEs that have been provided. After payment, the customer must confirm the tang payment has been done. The information presented is the date of confirmation of payment, booking code, customer name, the total amount to be paid, and the payment amount. To be able to know that payment was actually made, SMEs can check for mutations money to the account designated by the customer. If it has no mutation money coming in, then SMEs can provide validation of the payment made. 


\section{f. Shipping}

This page presents information delivery carried out by SMEs. Delivery of goods is based ordering payment products that have been validated by SMEs. If ordering these products have not been declared invalid, it will not be entered on the list of goods delivery. SMEs can make deliveries of goods to the designated shipping address. If there is a failed delivery, SMEs can provide information on the page and you can inform the customer that the delivery failed.

\section{g. Sales Returns}

These pages provide information about the sale of goods returned by customers. Customers can return the goods received based on evidence that such goods do not conform with the order or the goods are damaged upon receipt. Information sales returns based on information that the goods have been delivered. The information that can be presented is the code of delivery, date of delivery, the addressee, the products delivered, the products are returned, and the reason for the return of goods.

\section{h. Sales Report}

This page presents information about the sales report. SMEs can find the sales that have been made, which has not been done prduk booking payment by the customer, product orders that have been sent and failed messages, sales returns that occur as well as the cancellation of sales.

\section{i. Sales Graphics}

This page presents a graph of sales made by SMEs. Sales chart presented by product, and by the time such as per week, per month, per quarter, per semester or per semester.

\section{j. List of Customer}

This page presents information on SME customers. SMEs can find customers who make a reservation, customers who make payments, customers who make returns, as well as customers who do not cancel product orders. The information presented is a photo of the customer, the customer name, the domicile of the customer, contact information, e-mail address, as well as the product order history.

\section{k. Related Complaints SMEs}

This page is intended to provide information about the complaint made by SMEs. SMEs can complain to the Online Market Administrator concerning fraud committed by the customer, such as return the goods with other goods that do not correspond to the goods delivered. This page is used to protect SMEs from fraud committed by the customer.

1. Mailbox

This page presents information on messages between SMEs and customers. SMEs can make contact with the customer or by Administrator Online Market through the facilities Mailboxes.

m. Online Market Profile

This page is intended to provide information about the Online Market. SMEs identify the profile of the Market Online. In addition SMEs can contact the Market Administrator Online form contact person messages and information that has been provided.

\section{n. Log-Out}

This page provided SMEs out of these SMEs and leads directly to the visitors at home.

\section{Customer's Pages}

This page is only for customers. To be able to access a customer's site, the visitor can log-in on the log-in and must be registered as a customer in the Market Online. From this page, presented the following features, among others:

a. Customer's Account

These pages provide information about a customer's account. Customers can change the Username and Password periodically or not.

b. Customer's Profile

This page presents information on the customer profile. Customers can provide complete information regarding dirinyanya. The information that can be presented by the customer is the 
name, domicile, the number of contacts that can be contacted, e-mail address, and the address of the site if it has.

c. List of SME's

On this page, presented SMEs registered in the Online Marketplace as many as 20 SMEs per page. Customers can click the button detail on each column of SMEs that directly leads to the SME specific page. Customers can find out the profile of SMEs, the products are sold, a shopping cart, confirmation of payment, the contacts can be contacted, as well as other required.

d. List of Product

On this page are presented information about products owned SMEs as many as 20 products per page. Customers can click the button detail that leads directly to the specific page of SMEs in the product detail page. On that page, customers can find out information about a product in the form of product images, product specifications, prices, discounts, quantity of goods available, as well as other required. To be able to order products, so visitors must be registered as a customer in the Market Online.

e. Product's Order

These pages provide information about ordering products made by customers. Customers can find ordering products that have been paid or unpaid. In addition, the customer may cancel the subscriber products that have been done.

f. Payment Confirmation

This page presents information on the booking confirmation of payment products that have been done. Customers can make payments on the confirmation of the booking product that has been done. After confirming the payment, SMEs will perform validation on customer payment confirmation. If SMEs have declared the payment is valid, then the customer can also find validation for the confirmation that payment has been made.

g. Accept Goods

These pages provide information about the product delivered by SMEs to customers along with proof of receipt of goods by the recipient. Customers can see that the goods ordered have been delivered and accepted by the customer or the addressee.

h. Return of Goods

These pages provide information returns product purchases made by customers. Customers can inform SMEs that received product does not comply with the order, or damaged so returned. Purchase return shipment based on data that has been samapai or received by the customer.

i. Customer Complaint

This page is intended to provide information about the complaints made by customers. Customers can complain to the Administrator regarding the Market Online fraud by SMEs, such as not validate the confirmation payments made by customers in a given time period, eg 7 days or 14 days. This page is used to protect customers from fraud by SMEs.

j. Mailbox

This page presents information on messages between customers and SMEs. Customers can make contact with the customer or by Administrator Online Market through the facilities Mailboxes.

k. Online Market Profile

This page is intended to provide information about the Online Market. Customers can find out the profile of the Market Online. In addition, customers can contact the Market Administrator Online form contact person messages and information that has been provided.

1. Log-Out

This page is provided for customers out of these customers and leads directly to the visitors at home. 
m. Online Market Administrator's Page

Is a land for Online Market Administrator. On this page, presented the following features, among others:

n. Online Market Administrator's Account

These pages provide information about Online Market Administrator account. Online Market Administrator can change Username and Password periodically or not.

o. Online Market Profile Setting

These pages provide information about the Online Market. Online Market Administrator has the authority to be able to change the profile Online Market.

p. SME's Complaint

These pages provide information about complaints by SMEs. SMEs can sue the customer if the customer is concerned to commit fraud such as return the goods with other goods that do not correspond with items that have been sent and received. If there are complaints, then the Online Market Administrator may request confirmation from the customer concerned and if it can not provide conclusive evidence, then the customer may be incorporated in the black book and the customer is not able to make transactions in the Market Online.

q. Customer's Complaint

These pages provide information about complaints dilakukian by customers. SME customers can complain if the SME concerned commit fraud such as do not provide validation for the confirmation of payment the customer and not deliver goods that have been ordered even though has been declared valid upon confirmation of payment. If there are complaints, then the Online Market Administrator may request confirmation of the SMEs concerned and if it can not provide conclusive evidence, the SME can be included in the black book and SMEs are not able to make transactions in the Market Online.

r. SME's Black Book

This page presents information on SMEs that have been barred from joining in the Market Online. The information presented is based on complaints made by customers. Online Market Administrator can insert SMEs into the black book if there are some complaints made by customers and SMEs of the complaint can not provide conclusive evidence. Black book is intended to protect customers from fraud committed by SMEs and SMEs that have been entered in the black book can no longer transact in the Market Online.

s. Customer's Black Book

This page provides information about customers who have been barred from joining in the Market Online. The information presented is based on complaints made by SMEs. Online Market Administrator can enter the customer into the black book if there are some complaints made by SMEs and customers complained they can not provide conclusive evidence. Black book is intended to protect SMEs from fraud committed by customers and customers who have been entered in the black book can no longer transact in the Market Online.

t. Mailbox

These pages provide information about Online Market Administrator messages between SMEs and customers. Online Market Administrator can make contact with the customers and SMEs through the facilities of the Mailbox.

u. Log-Out

This page is out of the Administrator Online Market Online Market Site Administrator and leads directly to the visitors at home.

\section{RESEARCH CONCLUSION AND RECOMMENDATION}

\subsection{Conclusion}

Based on the discussion and description aboves, it can be concluded that Online market is a marketing solutions for problems faced by SMEs. With the Online Market, SMEs can market its products 
widely and have regulars. Online Market in order to work well, it would require presentation of complete and accurate information on SMEs and the products it offers, and the procedures are efficient at conducting transactions online. This is because the needs of customers to obtain adequate information about the products offered and the ease in conducting transactions online. In addition, customers have the right to be protected from fraud committed by SMEs and vice versa, SMEs have a right to be protected from fraud committed by customers.

Online market provides better opportunities to SMEs to market their products more widely and has regular customers. In addition, customers also receive adequate information on the product he wants and ease of transacting online. Thus, it can be concluded that the online marketing is a solution to the problems that faced by SMEs.

\subsection{Recommendation}

Quality research is heavily dependent on the individual skills of the researcher and more easily get personal biases and idiosyncrasies. Future research should be done by comparing this online marketplace design with the best practice of online marketplace wholeword.

\section{REFERENCES}

Fuady, M. (2005). Pengantar hukum bisnis. Bandung: PT. Citra Aditya Bakti

Hallberg, Kristin. 2008, A Market-Oriented Strategy For Small and Medium-Scale Enterprises, Discussion Paper Number 40, World Bank, Washington, D.C.

Ishak, Effendi. 2005. Artikel : Peranan Informasi Bagi Kemajuan UKM. Yogyakarta : Kedaulatan Rakyat.

Jogiyanto, H.M., 1999, Analisis dan Desain Sistem Informasi Pendekatan Terstruktur Teori dan Praktek Aplikasi Bisnis, Andi Offset, Yogyakarta.

Kadir, Abdul. 2008. Dasar Pemograman web dinamis mengunakan PHP. Yogyaarta, ANDI

Kotler, Philip. Manajemen Pemasaran, Edisi Milenium 1. Prenhailindo : Jakarta, 2002.

Poerwandari. E. K. 1998. Pendekatan Kualitatif dalam Penelitian Psikologi. Lembaga Pengembangan Sarana Pengukuran dan Pendidikan Psikologi (LPSP3) Fakultas Psikologi Universitas Indonesia, Jakarta

Purbo, O. W. (2001). Mengenal e-commerce. Jakarta: PT. Elex Komputindo

Ram, Sundaresan; Jagdish N. Sheth, 1989, Consumer Resistance To Innovations: The Marketing Problems and Its Solutions, The Journal of Consumer Marketing, Vol. 6 No. 2, Spring 1989

Sukarmi, (2008). Cyber law: kontrak elektronik dalam bayang-bayang pelaku usaha (cyberlaw indonesia). Bandung : TBO

Suparlan. P. 1994. Metodologi Penelitian Kualitatif. Program S-2 Kajian Wilayah Amerika Universitas Indonesia, Jakarta

Rohim, Taufik 2002, Sistem Informasi, ITB, Bandung.

http://www.beone-solution.com/blog/strategi-bisnis-ukm-pemasaran-yang-efektif-untuk-ukm-usahakecil-menengah/ (diakses terakhir pada tanggal 12 September 2016)

http://www.etalasebisnis.com/berita/ukm/2045/pemasaran-masih-menjadi-masalah-terbesar-bagi-umkmsurakarta.html diakses terakhir pada tanggal 12 September 2016

Republik Indonesia, Undang-Undang No. 9 Tahun 1995 tentang Usaha Kecil 
Jurnal Ilmiah Bidang Akuntansi dan Manajemen (JEMA) Vol. 14 No. 1 (2017)

http://riset.unisma.ac.id/index.php/jema

Republik Indonesia, Keputusan Presiden RI No. 99 Tahun 1998 tentang Bidang/Jenis Usaha yang dicadangkan untuk Usaha Kecil dan Bidang/Jenis Usaha yang Terbuka untuk Usaha Menengah atau Usaha Besar dengan Syarat Kemitraan

*) Aditya Hermawan, STIE ASIA Malang

**) Aniek Murniati, STIE ASIA Malang
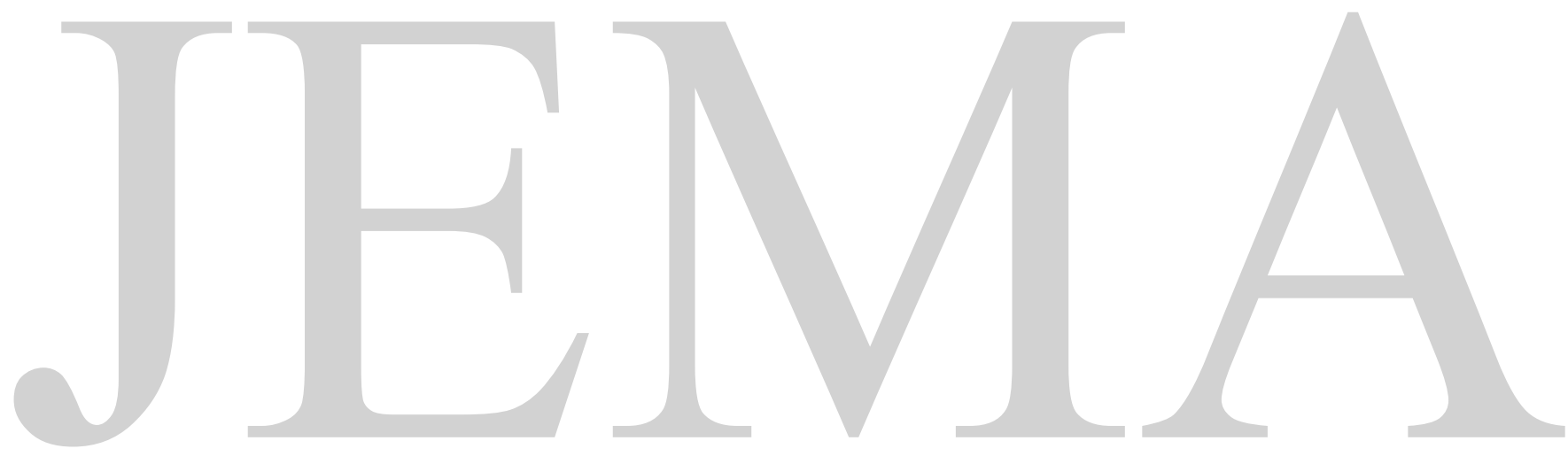